Indexed by

\title{
ONE OF THE APPROACHES TO SOLVE THE PROBLEM OF THE COST OF A PHASE TRANSITION HEAT ACCUMULATOR FOR A SOLAR HEAT SUPPLY SYSTEM
}

\section{Umerenkova Elina Vladimirovna}

Crossref Southwest State University,

Faculty of Construction and

Architecture, Department of Heat,

Gas and Water Supply,

ROAD Kursk, Russia

Key words: solar systems, heat supply, phase transition heat accumulator, heat-accumulating material

Cite article:

Umerenkova, E. V. [2021]. One of the approaches to solve the problem of the cost of a phase transition heat accumulator for a solar heat supply system. Journal of Applied Engineering Science, 19(1) 204 - 207. DOI:10.5937/jaes0-30067 


\title{
ONE OF THE APPROACHES TO SOLVE THE PROBLEM OF THE COST OF A PHASE TRANSITION HEAT ACCUMULATOR FOR A SOLAR HEAT SUPPLY SYSTEM
}

\author{
Umerenkova Elina Vladimirovna* \\ Southwest State University, Faculty of Construction and Architecture, Department of Heat, \\ Gas and Water Supply, Kursk, Russia
}

Based on the analysis of the Russian market of basic materials for phase-shifting heat accumulators (FPAT), including the issue of pricing policy, an attempt was made to reveal the dependence of the cost of a heat accumulator for a solar thermal supply system on operating and design parameters. In turn, to determine the latter, the method was used, which makes it possible to design FPAT with the given design and technological parameters, at a given minimum temperature of the coolant at the outlet of the accumulator, the known thermophysical characteristics of the coolant and heat storage material (TAM), including the phase transition temperature.

Key words: solar systems, heat supply, phase transition heat accumulator, heat-accumulating material

\section{INTRODUCTION}

Today's trends, including the regulatory framework, guide designers towards the development of energy-efficient housing [1] to [3]. This, in turn, implies, among other things, the use of alternative energy sources [4], [16].

However, today the inclusion of a heat supply system, for example, a solar hot water supply system, has a long payback period. Despite this, the relevance of the above issues is determined, first of all, by the strengthening of the tendency to use environmentally friendly thermal energy [5], [17]. In turn, the advisability of installing heat accumulators, including those with a heat-accumulating material (TAM), undergoing melting-solidification phase transitions, in systems with different modes of heat supply and consumption is obvious. It can also be systems for the utilization of secondary energy resources, in which periods of heat supply with capacities exceeding the required one alternate with time intervals when the heat output of the source is less than the calculated heat load of the consumer or is absent altogether (equal to zero).

Despite various attempts at technological improvement, the most common type of heat accumulators is shelland-tube devices that implement a passive method of heat exchange between the coolant and the TAM. It is assumed that the working fluid fills the annular space, and the supply (removal) of heat is carried out from the coolant (to the coolant) through a solid heat exchange surface, made, for example, in the form of a bundle of vertically arranged heat exchange tubes.

The design of such devices presupposes a preliminary determination of the mass (volume) of the heat storage material $\mathrm{M}$, the area of the heat transfer surface $\mathrm{F}$, and several other parameters.

In this work, the problem of estimating the cost of a phase-transition heat accumulator for a solar thermal supply system is solved based on the method of ther- mal calculation of a phase-transition heat accumulator (FPAT) of a shell-and-tube type, using a quasi-stationary model of its thermal state [6], the essence of which is to determine the dimensionless parameters of the heat accumulator (relative radius heat storage cell $r_{2}$ and the operating parameter $\omega$ ), the presence of which makes it possible to calculate the specific design characteristics of both a separate heat storage cell and the battery as a whole.

\section{THERMAL CALCULATION OF A PHASE TRANSITION HEAT ACCUMULATOR FOR A SOLAR HEAT SUPPLY SYSTEM}

The most typical variant of the thermal calculation of the heat accumulator is to determine the mass of the phase transition heat-accumulating material (TAM), the heating surface and the corresponding design parameters of the device at a given minimum temperature of the coolant at the outlet of the accumulator $t_{2 p}$ and the desired discharge time $T_{p} \geq T_{\min }$. Also known is the flow rate of the coolant G, its inlet temperature $\mathrm{t} 1$, as well as the thermophysical characteristics of the coolant and TAM, including the phase transition temperature $T_{f}$.

The presence of a flow rate of the cooling coolant makes it possible to estimate the cross-sectional area of the tubes $f_{t p}$. Having taken the tube diameter according to the assortment, we determine the required number of tubes and, accordingly, the FPAT heat-storage cells. This, in turn, allows us to find the Fourier number $F_{\text {otp }}$ for discharge time $T_{p}$ and calculate the relative outlet temperature $\theta_{2 \min }$.

To analyze the influence of various factors on the final cost of the device, the discharge process of the FPAT was calculated, while when choosing the initial data, both real operating conditions (hot water supply for domestic needs) and possible options for increasing the outlet temperature of the coolant were taken into account [3]. 


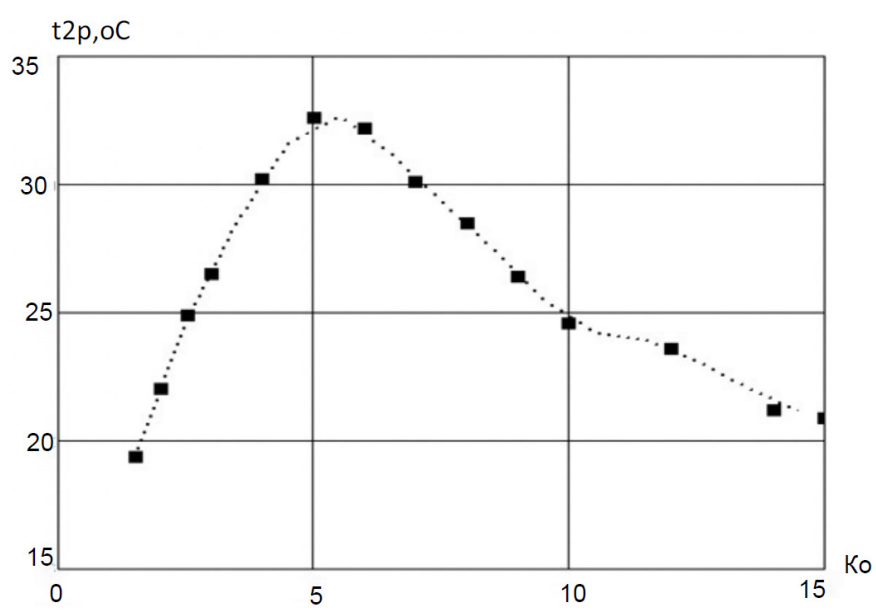

Figure 1: Dependence of the outlet temperature of the coolant at the end of the discharge process $t_{2 p}$ from the Kossovich criterion

The effect on the value of $t_{2 p}$ the Kossovich criterion, determined by the ratio of the latent and apparent heat of the process. Output temperature at the end of discharge with rising Ko grows, reaching a maximum, and then falls (Fig. 1).

The cost of the materials of the heat storage cell behaves simi. Thus, to increase the outlet temperature of the coolant (the most important technological parameter!) And reduce manufacturing costs, there is no need to use TAM with the maximum possible specific heat of the phase transition. It is enough to provide the optimal value of the criterion Ko, which is responsible for taking into account the effect of the phase transition.

Considering the above, we take the coolant flow rate as the initial data $\mathrm{G}=0,2 \mathrm{~kg} / \mathrm{s}$ (approximately corresponds to the water flow through an open water-folding device), the temperature of the heated water: at the inlet to the battery $\mathrm{t}_{1}=10^{\circ} \mathrm{C}$, at the exit (minimum, at the end of the discharge process) $-t_{2 p}=25^{\circ} \mathrm{C}$.

The algorithm for determining dimensionless parameters $\tilde{\omega}$ and $r_{2}$ [3] allows you to calculate the mass of the TAM filling the battery. Per one cell, we can write

$M_{\text {tcell }}=\tilde{\omega}_{\text {cell }} \cdot c_{v} \cdot G_{\text {cell }} \cdot \rho_{t} \cdot R_{1}^{2} / 2 \Lambda_{t}$,

and for the battery as a whole, meaning the parallel connection of heat exchange tubes (cells)

$M_{t}=\tilde{\omega}_{\text {cell }} \cdot c_{v} \cdot G \cdot \rho_{t} \cdot R_{1}^{2} / 2 \lambda_{t}$.

Where is:

$\Lambda_{t}$ - heat capacity of TAM in solid-state, $W / m^{\circ} \mathrm{C}$

$R_{1}$ - outer radius of the heat exchange tube, $m$

$\mathrm{C}_{\mathrm{v}}$ - heat capacity of the coolant, $\mathrm{kJ} / \mathrm{kg}{ }^{\circ} \mathrm{C}$

$\mathrm{P}_{\mathrm{t}}$ - density of TAM in solid-state, $\mathrm{kg} / \mathrm{m}^{3}$

$\tilde{\omega}_{\text {cell }}$ - mode parameter of a single battery cell.
Relations (1), (2) determine the useful mass of the TAM. At the same time, when placing the pipe system in a common casing, a part of the heat storage material will act as a filler for the voids between the heat storage cells. Estimates show that the share of this ballast part of TAM concerning the useful $M_{t}$ is slightly more than $30 \%$ and practically does not depend on the number of cells.

Knowledge of the mass $M_{\text {tcell }}$ allows you to determine the $H_{o}=M_{t} / R_{1}^{2} \cdot\left(r_{2}^{2}-1\right) \cdot \rho_{t} \cdot \pi$.

height (length) of the cell (more precisely, the height of the TAM in the solid-state in the cell) $\mathrm{H}_{0}$ as a:

It is assumed that the outer radius of the heat exchange tube $R_{1}$ is known. Its assessment at a given flow rate can be performed in the same way as is customary when calculating tubular heat exchangers by setting the speed of the coolant (as a rule, no more than $0.5 \mathrm{~m} / \mathrm{s}$ ).

According to objective selection criteria, such as melting point, the heat of phase transition, availability and non-toxicity, simple implementation of heat exchange due to a suitable level of phase transition temperature for low-temperature regimes of heat supply systems, particular interest for accumulating thermal energy is presenting technical paraffin [7] to [9]. Heat exchanger tubes are made of copper due to their high thermal conductivity and corrosion resistance [10] to [12].

\section{RESULTS OF COST ESTIMATION OF A PHASE TRANSITION HEAT ACCUMULATOR FOR A SOLAR HEAT SUPPLY SYSTEM}

The results of calculating the structural, weight, size and cost characteristics of FPAT (discharge time of FPAT $T_{p}=1$ hour; the relative temperature at the end of discharge $\left.\theta_{2 p}=0,357\right)$ are presented in tables $1-3$, for typical values (in the permissible range of cooling medium speed in heat exchange tubes) from minimal to marginal.

For tubes with a diameter of $10 \times 1 \mathrm{~mm}$ and the water velocity in them is $0.1 \mathrm{~m} / \mathrm{s}$, the minimum length of the heat-accumulating cells corresponds, which is certainly important from the point of view of the overall characteristics. However, the calculations suggest that the minimum length does not necessarily correlate with the lowest cost. As can be seen from the presented dependences, the costs for a single cell increase (due to the $\mathrm{M}_{\text {tcell }}$ increase in accordance with (1)) both with an increase in the speed (practically, linearly) and the diameter of the tubes.

\section{CONCLUSIONS}

The proposed approach to solving the problem of estimating the cost of a phase-transition heat accumulator for a solar heating system can be useful in the design of such devices, in particular, in the feasibility study of the parameters of a heat storage installation [13] to [15]. 
Table 1: Calculation results for water velocities $V=0.1, \mathrm{~m} / \mathrm{s}$ and different tube diameters

\begin{tabular}{|l|c|c|l|l|}
\hline \multicolumn{1}{|c|}{ tube area $\mathrm{f}_{\mathrm{tp}}$} & \multicolumn{3}{c|}{0,0080} \\
\hline tube diameter $\mathrm{d}_{\mathrm{tp}}$ & $\mathrm{mm}$ & $10 \times 1$ & $15 \times 1$ & $22 \times 1$ \\
\hline outer radius $\mathrm{R}_{1}$ & $\mathrm{~m}$ & 0,005 & 0,0075 & 0,011 \\
\hline number of tubes $\mathrm{n}_{\mathrm{tp}}$ & $\mathrm{pc}$ & 159 & 61 & 25 \\
\hline$\tilde{\mathrm{F}}_{\text {otp }}$ & & 29,42 & 13,08 & 6,079 \\
\hline$\tilde{\omega}$ & & 8,833 & 3,864 & 1,828 \\
\hline $\mathrm{r}_{2}$ & & 4,094 & 4,094 & 2,468 \\
\hline cell mass $\mathrm{M}_{\text {cell }}$ & $\mathrm{kg}$ & 5,46 & 14,25 & 34,81 \\
\hline cell height $\mathrm{H}_{\mathrm{o}}$ & $\mathrm{m}$ & 5,52 & 11,72 & 22,48 \\
\hline cell cost $\mathrm{C}_{\text {cell }}$ & rubles & 1112 & 3415 & 9423 \\
\hline total weight $\mathrm{M}_{\mathrm{o}}$ & $\mathrm{kg}$ & 868 & 855 & 870 \\
\hline total length $\Sigma \mathrm{H}_{\mathrm{o}}$ & $\mathrm{m}$ & 878 & 715 & 562 \\
\hline total cost $\mathrm{C}_{\mathrm{o}}$ & thous. rub & 176,7 & 208,3 & 235,6 \\
\hline
\end{tabular}

Table 2: Calculation results at water velocities $V=0.3, \mathrm{~m} / \mathrm{s}$ and different tube diameters

\begin{tabular}{|l|c|c|l|l|}
\hline \multicolumn{1}{|c|}{ tube area $f_{\text {tp }}$} & \multicolumn{3}{c|}{0,0080} \\
\hline tube diameter $\mathrm{d}_{\mathrm{tp}}$ & $\mathrm{mm}$ & 101 & $15 \times 1$ & $22 \times 1$ \\
\hline outer radius $\mathrm{R}_{1}$ & $\mathrm{~m}$ & 0,005 & 0,0075 & 0,011 \\
\hline number of tubes $\mathrm{n}_{\mathrm{tp}}$ & $\mathrm{pc}$ & 79 & 30 & 13 \\
\hline$\tilde{\mathrm{F}}_{\text {Otp }}$ & & 29,42 & 13,08 & 6,079 \\
\hline$\tilde{\omega}$ & & 8,833 & 3,864 & 1,828 \\
\hline $\mathrm{r}_{2}$ & & 4,094 & 4,094 & 2,468 \\
\hline cell mass $\mathrm{M}_{\text {cell }}$ & $\mathrm{kg}$ & 11,00 & 28,51 & 66,94 \\
\hline cell height $\mathrm{H}_{\mathrm{o}}$ & $\mathrm{m}$ & 11,11 & 23,45 & 43,24 \\
\hline cell cost $\mathrm{C}_{\text {cell }}$ & rubles & 2238 & 6833 & 18124 \\
\hline total weight $\mathrm{M}_{\mathrm{o}}$ & $\mathrm{kg}$ & 69 & 855 & 870 \\
\hline total length $\Sigma \mathrm{H}_{\mathrm{o}}$ & $\mathrm{m}$ & 878 & 704 & 562 \\
\hline total cost $\mathrm{C}_{\mathrm{o}}$ & thous. rub & 176,7 & 208,3 & 235,6 \\
\hline
\end{tabular}

Table 3: Calculation results at water velocities $V=0.5, \mathrm{~m} / \mathrm{s}$ and different tube diameters

\begin{tabular}{|l|c|c|l|l|}
\hline \multicolumn{1}{|c|}{ tube area $\mathrm{f}_{\mathrm{tp}}$} & \multicolumn{3}{c|}{0,0080} \\
\hline tube diameter $\mathrm{d}_{\mathrm{tp}}$ & $\mathrm{mm}$ & 101 & $15 \times 1$ & $22 \times 1$ \\
\hline outer radius $\mathrm{R}_{1}$ & $\mathrm{~m}$ & 0,005 & 0,0075 & 0,011 \\
\hline number of tubes $\mathrm{n}_{\mathrm{tp}}$ & $\mathrm{pc}$ & 32 & 12 & 5 \\
\hline$\tilde{\mathrm{F}}_{\text {otp }}$ & & 29,42 & 13,08 & 6,079 \\
\hline$\tilde{\omega}$ & & 8,833 & 3,864 & 1,828 \\
\hline $\mathrm{r}_{2}$ & & 4,094 & 4,094 & 2,468 \\
\hline cell mass $\mathrm{M}_{\text {cell }}$ & $\mathrm{kg}$ & 27,15 & 71,26 & 174,0 \\
\hline cell height $\mathrm{H}_{\mathrm{o}}$ & $\mathrm{m}$ & 27,41 & 58,63 & 112,4 \\
\hline cell cost $\mathrm{C}_{\text {cell }}$ & rubles & 5522 & 17082 & 47113 \\
\hline total weight $\mathrm{M}_{\mathrm{o}}$ & $\mathrm{kg}$ & 869 & 855 & 870 \\
\hline total length $\Sigma \mathrm{H}_{\mathrm{o}}$ & $\mathrm{m}$ & 877 & 704 & 562 \\
\hline total cost $\mathrm{C}_{\mathrm{o}}$ & thous. rub & 176,7 & 205,0 & 235,6 \\
\hline
\end{tabular}




\section{REFERENCES}

1. Krygina, A., Kotenko, E., Umerenkov, E. (2012). Method of thermal calculation of the phase-transition heat accumulator of the shell-and-tube type. Housing construction, no. 8, 38-40.

2. Sergeevich, Y. V., Evgenievna, S. N., Gennadievna, P. E., Vladimirovna, B. N., \& Emmanuel, S. [2019]. To the question of improving energy-saving and environmental characteristics of urban buildings. Journal of Applied Engineering Science, 17(4), 550-554.

3. Umerenkov, E. (2013). Development of heat accumulators on a phase transition for heat supply systems. Avtoref. Dis. Cand. Tech. Science. Kursk,18 p.

4. Federal Law of 23.11.2009 N 261-FZ (as amended of 29.07.2017) "On energy saving and on increasing energy efficiency and on amendments to certain legislative acts of the Russian Federation" (with amendments and additions coming into force from 01.01 .2018)

5. Kotenko, E. Umerenkov, V. (2013). Environmental aspects of using heat accumulators. Bulletin of the South-West State University. Series: Engineering and technology, no. 3, 111-113.

6. Umerenkov, E., Kotenko, E. (2012). Thermal calculation of a shell-and-tube heat accumulator on a phase transition based on a quasi-stationary approximation. News of the Southwest State university, no. 4(43), 211-216.

7. Levenberg, V., Tkach, M., Golstrem, V., Levenberg, V. (1991). Heat accumulation. Kiev: Tehnika, 112 p.

8. Saxena, A., Goel, V. (2013). Solar Air Heaters with Thermal Heat Storages. Chinese Journal of Engineering, vol. 2013, 11, DOI: 10.1155/2013/190279.

9. Saxena, A., Agarwal, N., Cuce, E. Thermal performance evaluation of a solar air heater integrated with helical tubes carrying phase change material. The Journal of Energy Storage. vol. 30:101406, DOI: 10.1016/j.est.2020.101406.

10. Umerenkov, Y., Umerenkova, E., Pakhomova, E., Semicheva, N. (2020). Process modelling of seasonal hot water supply heliosystem. E3S Web of Conferences, vol. 164, 13009.
11. Kurt, H. (2006). Experimental investigation of thermal performance of hot box type solar cooker. Journal- Energy Institute, vol. 79, no. 2, 120-124, DOI: 10.1179/174602206X103549.

12. Siuta-Olcha, A., Cholewa, T., Dopieralska-Howoruszko, K. (2020). Experimental studies of thermal performance of an evacuated tube heat pipe solar collector in Polish climatic conditions. Environmental Science and Pollution Research, vol. 24, no. 6, DOI: 10.1007/s11356-020-07920-3.

13. Sen, H., Cuce, P.M. (2020). Numerical performance modelling of solar chimney power plants: Influence of chimney height for a pilot plant in Manzanares, Spain Sustainable. Energy Technologies and Assessments. vol. 39:100704. DOI: 10.1016/j. seta.2020.100704.

14. Abd Ali, L.M., Issa, H.A. (2018). Hybrid power generation using solar and wind energy, Molod. Uchen., no. 7, 19-26. https://moluch.ru/archive/193/48444.

15. Kuznetsov, P. N., Abd, A. L. M., Kuvshinov, V. V., Issa, H. A., Mohammed, H. J., \& Al-bairmani, A. G. [2020]. Investigation of the losses of photovoltaic solar systems during operation under partial shading. Journal of Applied Engineering Science, 18(3), 313320.

16. Saxena, A., Agarwal, N., Cuce, E. (2020). Thermal performance evaluation of a solar air heater integrated with helical tubes carrying phase change material. Journal of Energy Storage, vol. 30,101406, DOI: 10.1016/j.est.2020.101406.

17. Saxena, A., Verma, P., Srivastava, G., Kishore, N. (2020). Design and thermal performance evaluation of an air heater with low cost thermal energy storage. Applied Thermal Engineering, vol. 167, 114768, DOI: 10.1016/j.est.2020.101406. 